\title{
A Review on Thermochemical Treatment of Biomass: Pyrolysis of Olive Mill Wastes in Comparison with Other Types of Biomass
}

\author{
M. Y. GUIDA ${ }^{1,2 *}$, A. HANNIOUI ${ }^{1}$
}

\begin{abstract}
Each year, a great quantity of olive oil is produced by the unit mill of trituration. This activity generates two by-products named olive mill wastewater and olive mill solid waste representing major potential waste and environmental problem. However, there is growing interest in pyrolysis as a technology to treat wastes to produce valuable oil, char and gas products. The major important aim of waste pyrolysis is to produce liquid fuel or bio-oil, which is easy to store, transport and can be an alternative to energy source. The key influence on the product yield is the type of biomass feedstock and operating parameters (especially temperature and heating rate). It is important to investigate the effect of variables on response yield and impulse about their optimization. This study reviews operating variable from existing literature on olive mill wastes (OMSW and OMWW) in comparison with various types of biomass. The major operating variables include type of feedstock, final temperature of pyrolysis, heating rate and particle size. The scale of this paper is to analyse the influence of operating parameters on production of pyrolysis bio-oil, char and gaseous products.
\end{abstract}

Keywords: thermochemical treatment, pyrolysis, olive mill wastes, biomass, bio-oil, char, gas

\section{Introduction}

The olive tree plays a vital and viable role in the economy, ecology and social life of the Mediterranean countries (Fig. 1). There are more than 8 million ha in production, corresponding to approximately $96 \%$ of the world olive cultivation. Morocco is one of the famous Mediterranean countries in production of olive oil; the olive growing sector plays a very important role in the social scale and economic area. It takes part in fixing populations in rural environment while offering more than 15 million work days. With a national production which exceeds 750000 tons of olive oil (Fig. 2), Morocco

\footnotetext{
* Corresponding author. E-mail: myassineguida@gmail.com

${ }^{1}$ Laboratoire de Chimie Organique et Analytique, Faculté des Sciences et Techniques de Béni-Mellal, Univers ité Sultan Moulay Slimane, BP 523, 23000 Béni-Mellal, Morocco

${ }^{2}$ Laboratoire Interdisciplinaire de Recherche des Sciences et Techniques, Faculté polydisciplinaire de Béni-Mellal, Univers ité Sultan Moulay Slimane, BP 592, 23000 Béni-Mellal, Morocco
} 


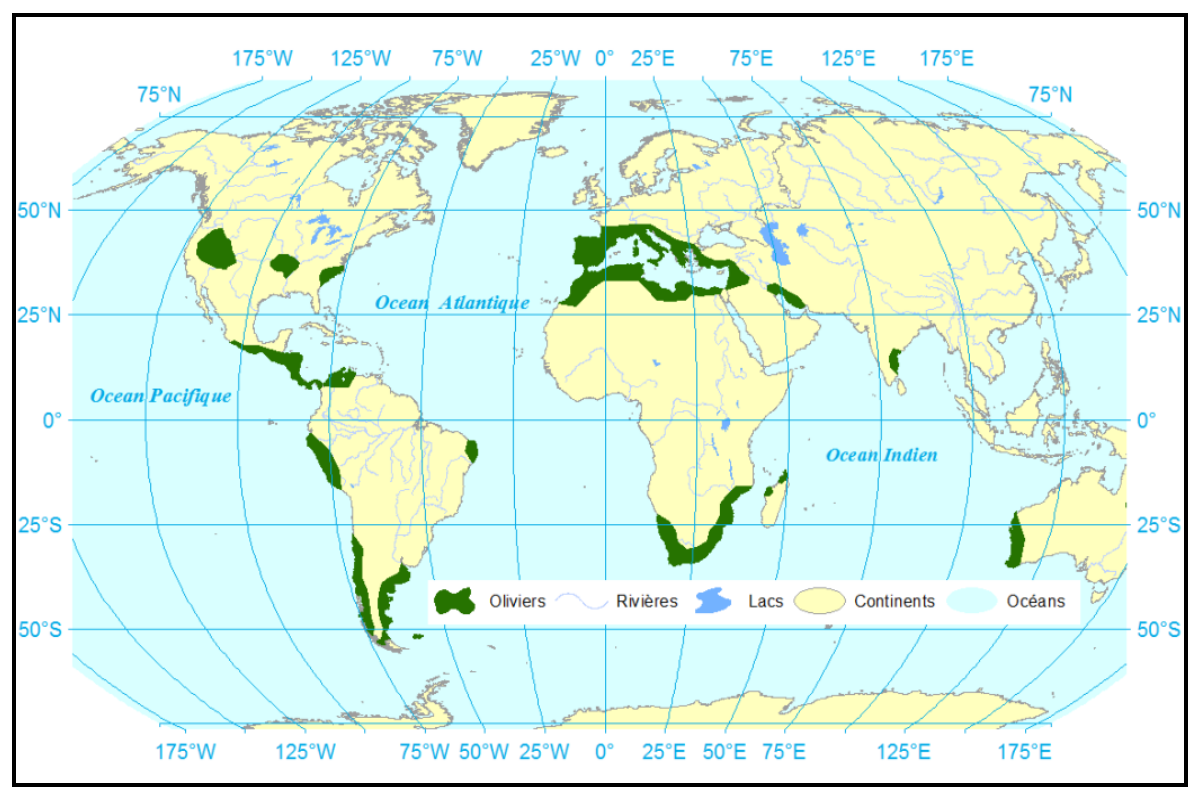

Fig. 1. Area distribution of international olive trees [4]

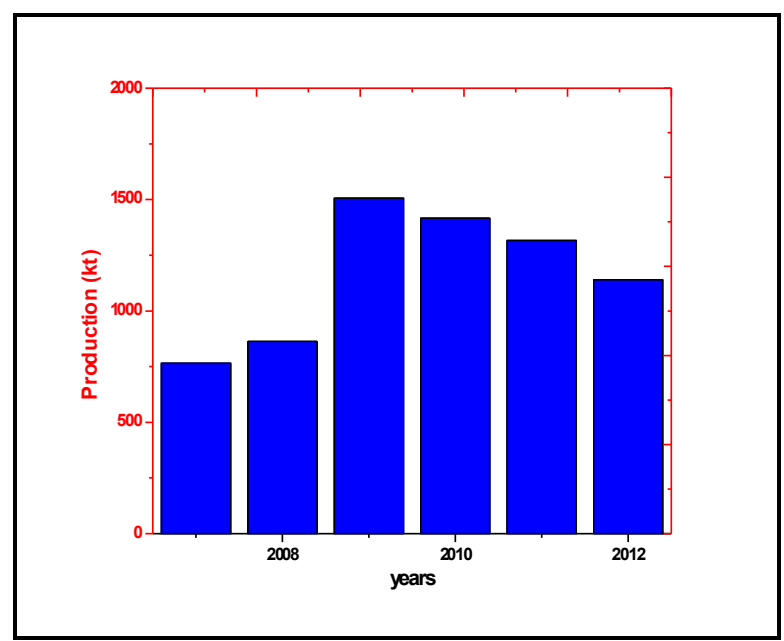

Fig. 2. Evolution of the production of the olive oil in Morocco [7]

occupies the $6^{\text {th }}$ rank after Tunisia, Greece, Turkey, Italy and Spain. Besides oil as the principal product, the olive oil industry produces and procreates great quantities of wastes that may have a great impact on land and water environments because of their high phytotoxicity [1-4]. There are two by- 
products: a solid waste called olive mill solid waste (OMSW) and a liquid waste named olive mill wastewater (OMWW). The annual quantities of olive mill solid waste were estimated at more than 180000 tons, while the olive mill wastewater represent a volume which exceeds $250000 \mathrm{~m}^{3}$. According to the estimates; $25 \mathrm{~kg}$ of olive leaves are produced by a tree a year. The composition of olive mill wastes is not constant (quantitatively and qualitatively) and it varies according to the soil and climate conditions of the production site, olive cultivar, ripening state of the olives, composition of the vegetation water, olive oil extraction process and storage time $[5,6]$.

In Morocco, the existence of the traditional mills (Mâasras) (Fig. 3), semi-industrial and industrial units is the most dominant characteristic in the sector of olive trituration. The produced amount of solid and liquid residues differs according to the technology applied for the extraction of olive oil. There are two oil extraction technologies: traditional pressing and the centrifugation method (Table 1). Traditional pressing was applied for many centuries [7-9]. However, in the last decades three-phase and two phase centrifugation processes have been applied by the majority of olive mills. Several studies have proven the negative effects of these wastes (olive mill solid waste and olive mill wastewater) on soil microbial populations and even in air medium. Therefore, there is a need for guidelines to manage these wastes through technologies that minimize their environmental impact and lead to a sustainable use of resources [10-15].

Table 1. Matter assessment of olive mill solid waste and olive mill wastewater

\begin{tabular}{|c|c|c|c|}
\hline Processes of trituration & OMWW & OMSW & References \\
\hline Biphasic & $10 \mathrm{Kg}$ & $70 \mathrm{Kg}$ with $60-70 \%$ of moisture & {$[20,21]$} \\
\hline Press Triphasic & $40 \mathrm{Kg}$ & $40 \mathrm{~kg}$ with $30-40 \%$ of moisture & {$[22]$} \\
\hline Triphasic with centrifugation & $>100 \mathrm{Kg}$ & $55 \mathrm{Kg}$ with $40-50 \%$ of moisture & {$[23]$} \\
\hline
\end{tabular}

R. Loussert et al. and A. Achkari-Begdour [16, 17] suggested solutions and alternatives to fight against the pollution of environment by olive mill waste. Among the principal ways of valorization, one finds thermochemical conversion. The thermochemical treatment of olive mill wastes such as olive mill solid waste (OMSW) and olive mill wastewater (OMWW) (which are regarded as biomass containing cellulose hemicelluloses and lignin) (Fig. 4) to useful end products can occur through one of several ways: pyrolysis, gasification, combustion and liquefaction. Pyrolysis is considered to be the starting points of all thermochemical conversion technologies (Fig. 5) be- 


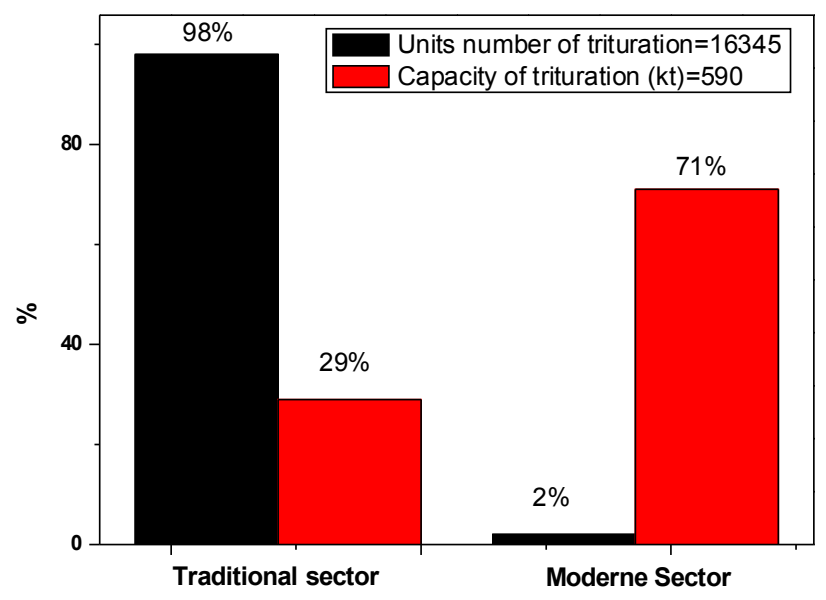

Fig. 3. Characteristic of the processing sector of the olive oil in Morocco [7]

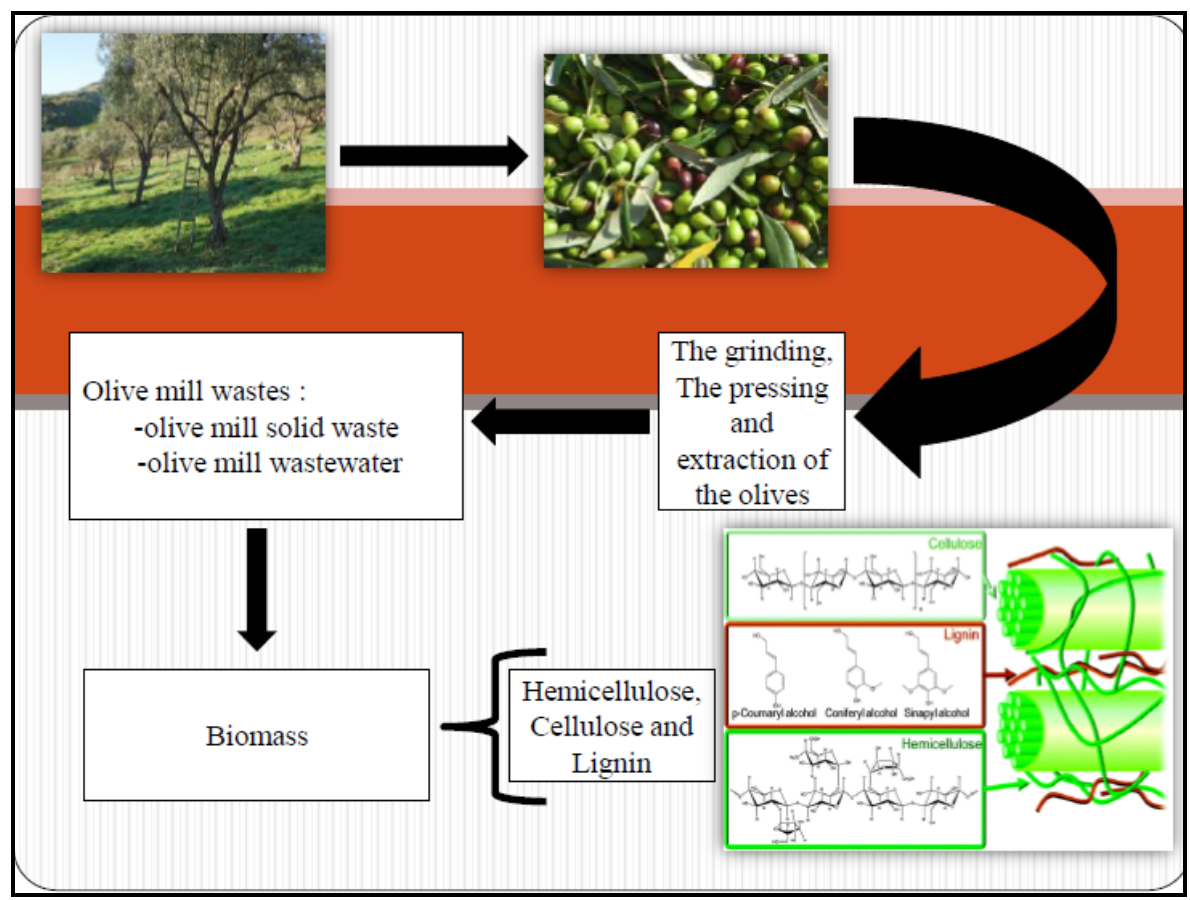

Fig. 4. Extraction and rejections of olive oil production 


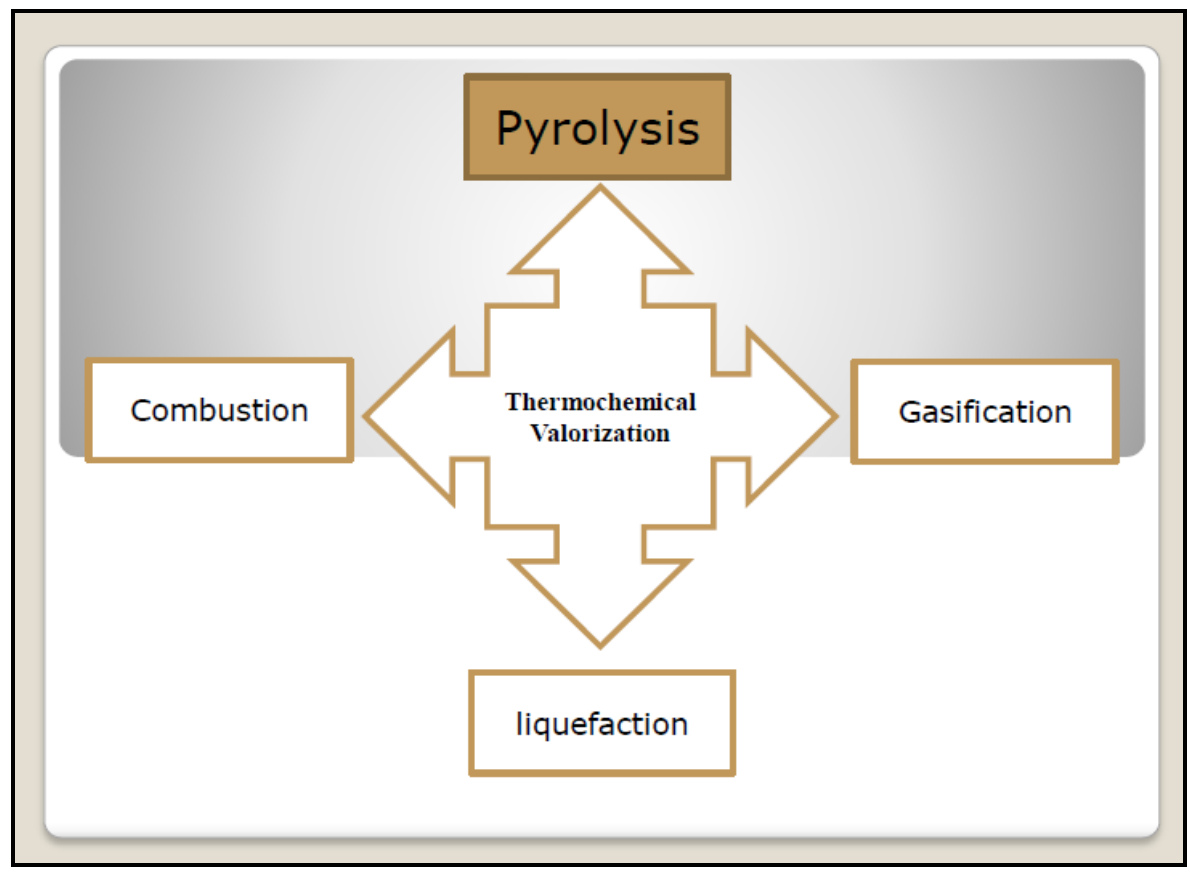

Fig. 5. Various ways of thermochemical valorization

cause it involves all chemical reactions to form liquid, solid and gas as the main products with zero concentration of oxygen [16].

Biomass as a form of energy source maybe utilized in two different ways: indirectly by converting it into solid, liquid or gaseous fuels, and directly by burning the biomass. Various types of wastes such as olive mill wastes, waste paper, agricultural waste, etc. are treated as biomass because like natural biomass these waste materials also are a mixture of non-organic and organic compounds and can be processed to get energy. Biomass is one of the most promising sources of alternative energy which can solve the problem of energy crisis in the world up to some extent due to its potential availability $[17,18]$. Besides, the use of biomass can also reduce the problem of pollution. It is the only renewable energy source which can be converted into three different products: liquid fuel, solid fuel and gaseous fuel. The relative amount of each product depends on the properties of the biomass, the type of pyrolysis process and operating parameters [19]. Decomposition of biomass at medium temperature $\left(400-550{ }^{\circ} \mathrm{C}\right)$ favors the production of liquid oils at short residence time. At low temperature, char is a dominant product. At higher temperature, gaseous products increase with rising tem- 
perature. According to the literature, the yield of liquid, solid and gaseous products can be divided into three temperature ranges: low temperature carbonization $\left(\leq 400{ }^{\circ} \mathrm{C}\right)$ (this review does not include discussion on carbonization), fast pyrolysis $\left(\geq 500^{\circ} \mathrm{C}\right.$ ) and slow pyrolysis (low heating rates of biomass) [20-23].

In this paper, the pyrolysis of biomass and especially olive mill wastes in comparison with various types of biomass is reviewed in terms of the range of pyrolysis conditions used. The influence of processes parameters on the liquid, solid and gaseous yields and composition of the products from the pyrolysis of different biomass are discussed. The fuel properties of the oils and their detailed chemical composition are discussed. The characteristics of the chars and gas composition are presented in detail.

\section{Characterization of Olive Mill Wastes}

\subsection{Physico-chemical characteristics}

Besides the olive oil which is the principal product, the olive growing activity produces three other by-products. The two first are solid, the third is liquid. The quantities produced of these by-products depend closely on the process applied at trituration. The physico-chemical characteristics of the olive mill wastewater are rather variables. The edaphic conditions, the maturity of olives, the variety, the climate, the method of culture and the mode of oil extraction are the factors which influence the physico-chemical composition of olive mill wastewater [24, 25].

The OMWW is characterized by a turbid aspect with a color which varies from brown to brown-reddish to black. As shown in Table 2, this liquid waste is acid ( $\mathrm{pH}$ from 2.24 to 5.9), has a strong load of saltworks (content of potassium salts $<<17.10 \mathrm{~g} / \mathrm{l}>>$ and phosphates), rich in organic matters and non-biodegradable polyphenols. Theses effluents are characterized by a high conductivity due especially to the ions potassium, chloride, calcium and magnesium (about 5 to $12 \mathrm{mS} / \mathrm{cm}$ ) [25, 26].

Olive mill solid wastes are solid residues resulting from the first pressure or centrifugation and are constituted of pulps and stone of olives. From Table 3, one can say that the olive solid waste is composed of a fraction which contains lignin which comes from the fragment of stones and of another fraction rich in celluloses and hemicelluloses and in the least of proteins and residual oil. In general, the composition varies according to the varieties of olives tritured and the technique used in extraction [24, 27]. 
Table 2. Physicochemical composition of OMWW

\begin{tabular}{|c|c|c|}
\hline Parameters & OMWW & References \\
\hline $\mathrm{PH}$ & $2.24-5.9$ & {$[25,26,27]$} \\
\hline Conductivity $(\mu \mathrm{S} / \mathrm{m})$ & $5.5-10$ & {$[28,27,29]$} \\
\hline Total carbon organic $(\mathrm{g} / \mathrm{L})$ & $20.19-39.8$ & {$[30,31]$} \\
\hline $\mathrm{BOD}(\mathrm{g} / \mathrm{L})$ & $35-132$ & {$[32,33]$} \\
\hline $\operatorname{COD}(\mathrm{g} / \mathrm{L})$ & $30-320$ & {$[34,32]$} \\
\hline Organic matter (\%) & $57.2-62.1$ & {$[26,35]$} \\
\hline Phénols (\%) & $0.63-5.45$ & {$[36,37]$} \\
\hline Dry matter & $6.33-7.19$ & {$[38,29]$} \\
\hline $\mathrm{P}(\%)$ & 0.19 & [37] \\
\hline $\mathrm{K}(\%)$ & $0.44-5.24$ & {$[27,28]$} \\
\hline $\operatorname{Mg}(\%)$ & $0.11-0.18$ & {$[31,27]$} \\
\hline
\end{tabular}

Table 3. Characteristics and chemical composition of OMSW

\begin{tabular}{|c|c|c|}
\hline Parameters & OMSW & References \\
\hline Moisture & $7.3-7.4$ & {$[40,41]$} \\
\hline Volatile matter & $66.6-74.8$ & {$[40,41]$} \\
\hline Ash & $2.16-5.1$ & {$[40,41]$} \\
\hline Carbon fix & $12.8-23.85$ & {$[40,41]$} \\
\hline Hemicellulose & $15.91-44$ & {$[42,44]$} \\
\hline Cellulose & $34.90-47.6$ & {$[43,42]$} \\
\hline Lignin & $45-48.4$ & {$[44,45]$} \\
\hline
\end{tabular}

\subsection{Microbiological characteristics}

From microbiological point of view, one can say that there is an absence of pathogenic microorganisms in the effluent liquid (OMWW) from olive growing activities. This does not pose any problem from health perspective, 
except for some yeasts and moulds which are able to develop [28]. The brown pigments or catecholmelaninic and the action exerted by phenols monomeric act on the antimicrobic power of the effluents of olive oil mill. The latter act on the bacteria by denaturing cellular proteins and by damaging the membranes [29]. These effluents can also inhibit the activity of the symbiotic bacteria which fixes nitrogen by inhibiting the activity of the digestive enzymes and/or by precipitating nutritional proteins.

\section{Thermochemical Technologies}

The most important thermochemical methods of converting biomass are: pyrolysis, liquefaction, combustion and gasification, as shown in Figure 6. Each method is different and employs different equipment and gives a different variety of product. Figure 6 presents some product from biomass conversion technology [28-31].

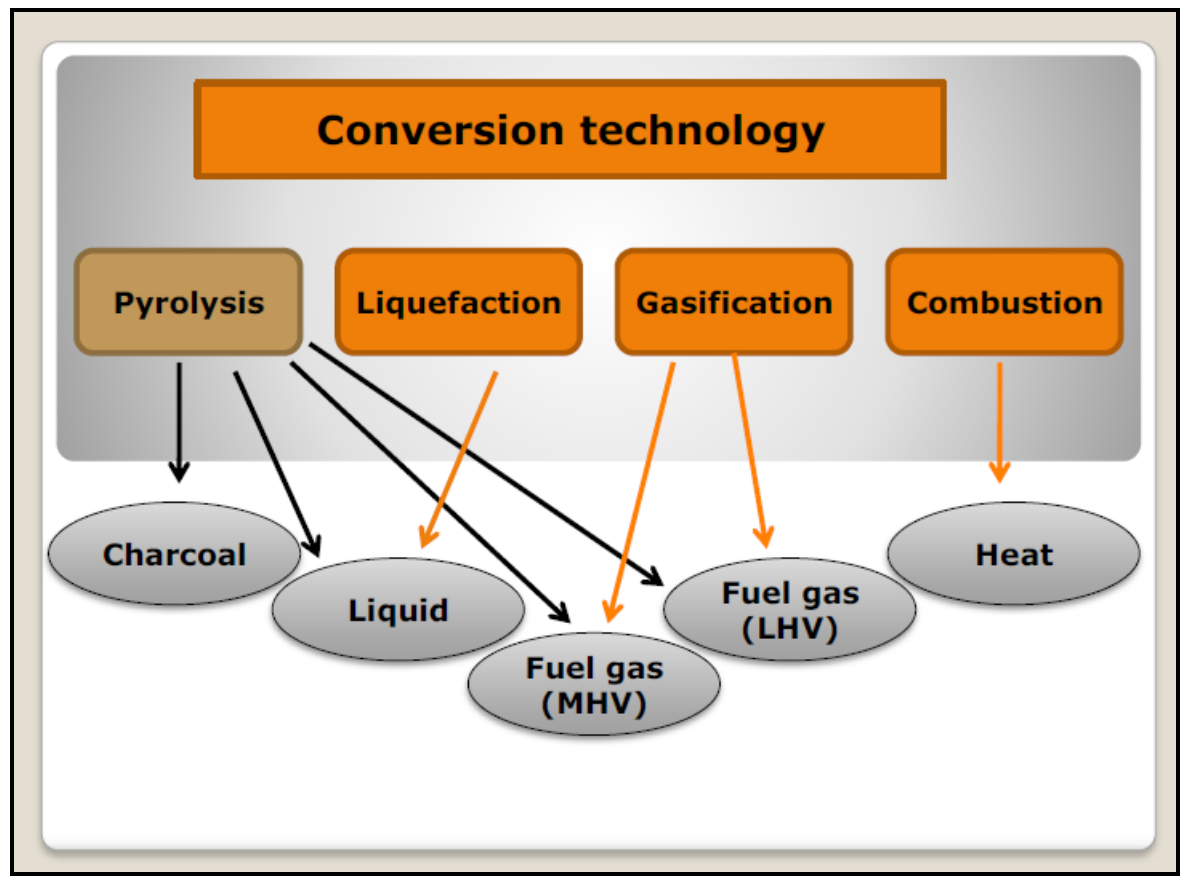

Fig. 6. Products resulting from various conversion technologies 


\subsection{Pyrolysis and its products}

Pyrolysis is a thermochemical decomposition process in which organic material such as biomass (olive mil wastes, sunflower bagasse, nut shell, etc.) is renewed into a volatile matter and carbon rich solid by heating in the absence of oxygen (oxidizing agent) [24, 25]. The volatile matter of this process is partly condensed to a mixture of condensable and non-condensable gases. The first is liquid fraction named bio-oil or tar, the solid product issue from this process is called bio-char or char and is generally composed of carbon (high content of carbon), the liquid product called bio-oil is the most important product, is used and stored for energy production [21, 32, 33].

The process of pyrolysis is very complex, to comprehend it requires a quite complete and thorough study. The most accepted theory is that primary vapors are first produced, the characteristics of which are most influenced by temperature and heating rate [34]. Yields of liquid products known as bio-oil issue from pyrolysis can consequently be influenced by the rate of reaction, with flash or fast pyrolysis at low temperatures of typically $450-600{ }^{\circ} \mathrm{C}$ giving the highest liquid yields and increasingly high final temperatures giving gradually higher gas yields and lower liquid yields [35].

It is very important to distinguish between primary products or oils, and secondary products or tars, and to understand the difference in properties between slow pyrolysis products or secondary oils or tars and flash pyrolysis liquids or primary oils $[33,35]$. These latter have a tendency to have a lower viscosity, be more stable under ambient conditions, more homogenous and less sensitive to water contamination due to great miscibility with water. This liquid product is characterized by a high oxygenated hydrocarbon with an appreciable proportion of water from both the reaction product and the original feed moisture.

At the same time, solid char may also be present [32]. These properties make it relatively unstable in both physical and chemical terms and may cause problems in utilization and upgrading. The production of char or charcoal is obtained when the conditions of pyrolysis are optimized; this occurs in slow pyrolysis with reaction times of hours or days. At the very high heating rates encountered in flash and fast pyrolysis very low char yields result, and they have been reported as yielding zero under some process conditions. The low char yield from flash pyrolysis could be integrated into the bio-oil to give a higher yield of liquid fuel [36-39].

The gaseous product yield from pyrolysis is usually a lower heating value fuel gas of around $4-9 \mathrm{MJ} / \mathrm{Nm}^{3}$, or a higher calorific value fuel gas of about $14-22 \mathrm{MJ} / \mathrm{Nm}^{3}[24,37]$. The heating value is enhanced if the gas is 
used warm, due to the sensible heat and the comparatively high tar content. The gas may be used for process heating, exported for sale, feed drying or power generation.

\subsection{Pyrolysis process parameters}

In pyrolysis, the reaction conditions are very important. Bio-oil, char and gas production through pyrolysis are influenced by the process parameters like type of feedstock, final temperature, heating rate, particle size and many more [39]. Hereinafter we discuss some of these important process parameters:

\subsubsection{Type of feedstock}

The chemical structure and major organic components in olive mill wastes and various types of biomass are enormously important in the development of processes for producing derived chemicals and fuels [40-42]. The major organic components can be classified as hemicellulose, cellulose and lignin, with other components such as extractives and minerals. Hemicelluloses are complex polysaccharides, are soluble in dilute alkali and consist of branched structures, which differ considerably among the various biomass types. Cellulose is insoluble in water, forms the skeletal structure of most terrestrial biomass, while lignins are highly branched, substituted, mononuclear aromatic polymers in the cell walls of certain biomass [39, 43]. At pyrolysis process, the main biomasses such as olive mill solid waste, olive mill wastewater, nut shell, sugar cane bagasse and other types of biomass, components contribute to product yields mainly as follows: hemicelluloses and cellulose components provide the volatile pyrolysis products, while the lignin predominantly forms a charred residue $[24,26]$.

J. Jauhiainen et al., A. Demerbas, A. Chouchene et al., F. Ros et al., A. Morisot, M. Mebirouk, I. Fki, I. Kapellakis et al., Y. Yacoub [44-54] were working on the pyrolysis of several agricultural types of biomass (Fig. 7), these researches showed that condensable and non-condensable gas yields and char differ from one kind of biomass to another. Besides, the nature and composition of biomass have a remarkable effect on the oil yield and their compositions. V. Minkova et al. [72], worked on the pyrolysis of various types of biomass (olive waste, straw, misk, birch, bagasse) under identical conditions (final temperature: $750{ }^{\circ} \mathrm{C}$, time of treatment at this temperature: $2 \mathrm{~h}$ ); they showed that the yields of pyrolysis products (char, bio-oil, gastlosses) are different. Minerals and extractives have an influence on 
product yields, in particular they contribute to the formation of char, and have a catalytic effect on pyrolysis reaction leading to increased char yields. Ilknur Demiral et al. [74] studied the effect of catalysts on the pyrolysis of olive wastes in comparison with hazelnut bagasse, and they showed that catalysts influence product yields of pyrolysis, while decreasing the yield of bio-oil, increasing the yield of char and influencing the composition of biooils and bio-char. They showed that bio-oil yields decreased as the catalyst ratio increased, the bio-oil yield from olive bagasse, which was $37.68 \%$ without catalyst, reached the value of $36.67 \%$, the bio-oil yield decreased to about $2.68 \%$. Goergios Taralas et al. [68] studied the pyrolysis of olive residue under nitrogen atmosphere; they made a comparison between noncatalyst and catalyst pyrolysis and they showed that there is a great difference between pyrolysis with catalysts and pyrolysis without catalysts.

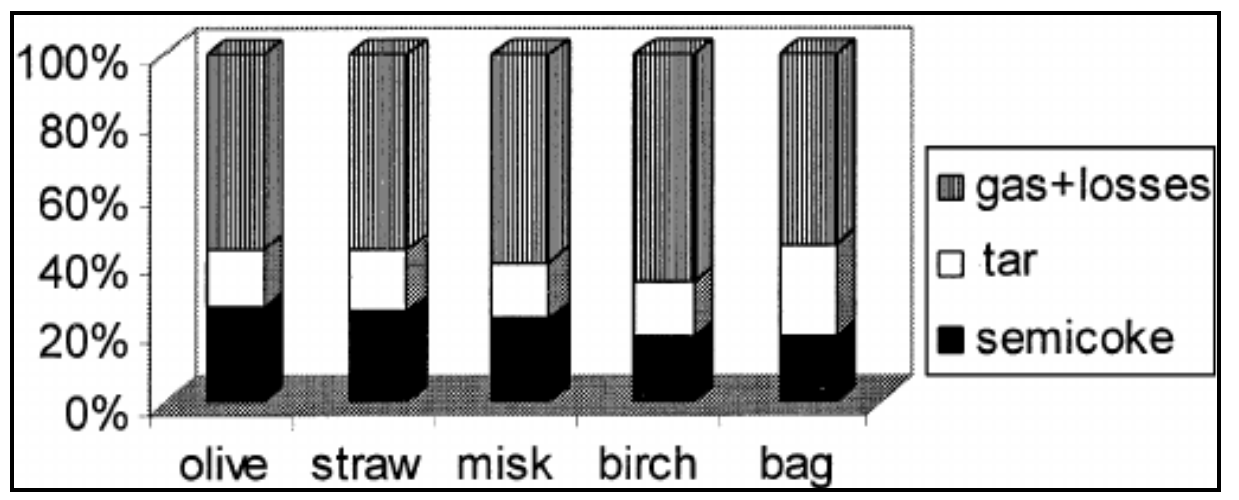

Fig. 7. Yield product obtained in pyrolysis of the selected raw materials in nitrogen [72]

\subsubsection{Particle size}

Particle size is one of the most important factors which should be taken care of in the pyrolysis process (Table 4); it has a considerable effect on the heat and mass transfer phenomena of pyrolysis. On increasing the particle size, the distance between the surface of the input biomass and its core increases which retards the rapid heat flow from the hot to cold end. Influence of size particles is considered important on the yield and properties of liquid oil produced [47-49]. Understanding the effect of particle size on pyrolysis process products yields may lend a hand to optimizing residence times. Several researches [24-28] concluded that the increasing particle size causes reduction in the liquid yields because secondary reactions activities leading 
to increases in gas yields and unpredicted higher yield of liquids with larger biomass particles are possibly due to differences in the types of biomass used during pyrolysis [40].

Table 4. Yield of products obtained at different particle sizes of various biomasses [67]

\begin{tabular}{|c|c|c|c|}
\hline Biomass & Olive waste & Straw & Wood \\
\hline Particle size $(\mathrm{mm})$ & $0.5-0.8$ & $0.5-1.0$ & $0.5-0.8$ \\
\hline Temperature $\left({ }^{\circ} \mathrm{C}\right)$ & 800 & 800 & 800 \\
\hline Bio-oil yield $(\mathrm{wt} \%)$ & 1.1 & 0.9 & 1.1 \\
\hline Char yield $(\mathrm{wt} \%)$ & 20.0 & 13.2 & 5.8 \\
\hline Gas yield $(\mathrm{wt} \%)$ & 61.0 & 75.8 & 81.1 \\
\hline Water and losses & 17.9 & 10.1 & 12.0 \\
\hline
\end{tabular}

Ayhan Demirbas [73] studied the effect of particle size on bio-char yield from pyrolysis of agricultural residues such as olive husk in comparison with corncob and tea waste. He showed that the bio-char yield increased with growing particle size of the samples, whereas, at a high temperature with small particles the bio-char yield decreased. He showed that the decrease for olive husk was $56.4 \%$ (from 44.5 to $19.4 \% \mathrm{wt}$ ) for particle size between 1.5 and $2.2 \mathrm{~mm}$ when the temperature was increased from 450 to 1250 $\mathrm{K}\left(170\right.$ to $900{ }^{\circ} \mathrm{C}$ ), in comparison, the decrease for the corncob was $81.4 \%$ ( from 30.6 to $5.7 \% \mathrm{wt}$ ) at the same conditions. Zanzi. R et al. [67] studied the pyrolysis of olive waste and straw in comparison with wood at high temperature $\left(800-1000{ }^{\circ} \mathrm{C}\right)$. They used different particle size $(0.5-0.8 \mathrm{~mm}$ for olive waste and 0.5-1.0 $\mathrm{mm}$ for straw) and they noticed that this parameter had an influence on char, bio-oil and gas yields and on surface area and the composition of bio-char. A. Morisot, M. Mebirouk, I. Fki, I. Kappellakis and Y. Yacoub [50-54] recommended and reported that medium particle size yielded maximum liquid compared to smaller and larger feed sizes. A. Pûtun et al. [69] have established the effect of particle size on the pyrolysis yields, they showed that particle size $\left(D_{p}\right)$ ranges between 0.425 and 0.85 $\mathrm{mm}$ give better yields than particle size between 0.85 and $1.8 \mathrm{~mm}, \mathrm{D}_{\mathrm{p}}<0.425$ $\mathrm{mm}$ and $\mathrm{D}_{\mathrm{p}}>1.8 \mathrm{~mm}$. 


\subsubsection{Heating rate}

Heating rate is the most important parameter after temperature and several researchers showed the influence of this parameter on products yields from pyrolysis of various types of biomass (Fig. 8). At low heating rate the possibility of secondary pyrolysis reactions can be ruled out. Low heating rate also ensures that no thermal cracking of biomass takes place resulting in more biochar yield [55-60]. Concerning high heating rate, it backs the fragmentation of biomass and increases the gaseous and liquid yield, limiting the possibility of formation of the biochar. It is likely to enhance the depolymerisation of biomass into primary volatile components which in the end retard the char yield [61-65]. At high heating rate the secondary pyrolysis dominates and these secondary reactions aid the formation of gaseous products. The effect of heating rate on biochar, liquid and gaseous products yields is more noticeable. Sensoz et al. [71] reported that bio-oil pyrolysis yields of olive bagasse decrease with the increase of heating rate. They showed that at $10^{\circ} \mathrm{C} / \mathrm{min}$, the maximum yield of bio-oil was $34.4 \%$, while at $50{ }^{\circ} \mathrm{C} / \mathrm{min}$ it was $31.8 \%$. Concerning the gaseous product, they showed

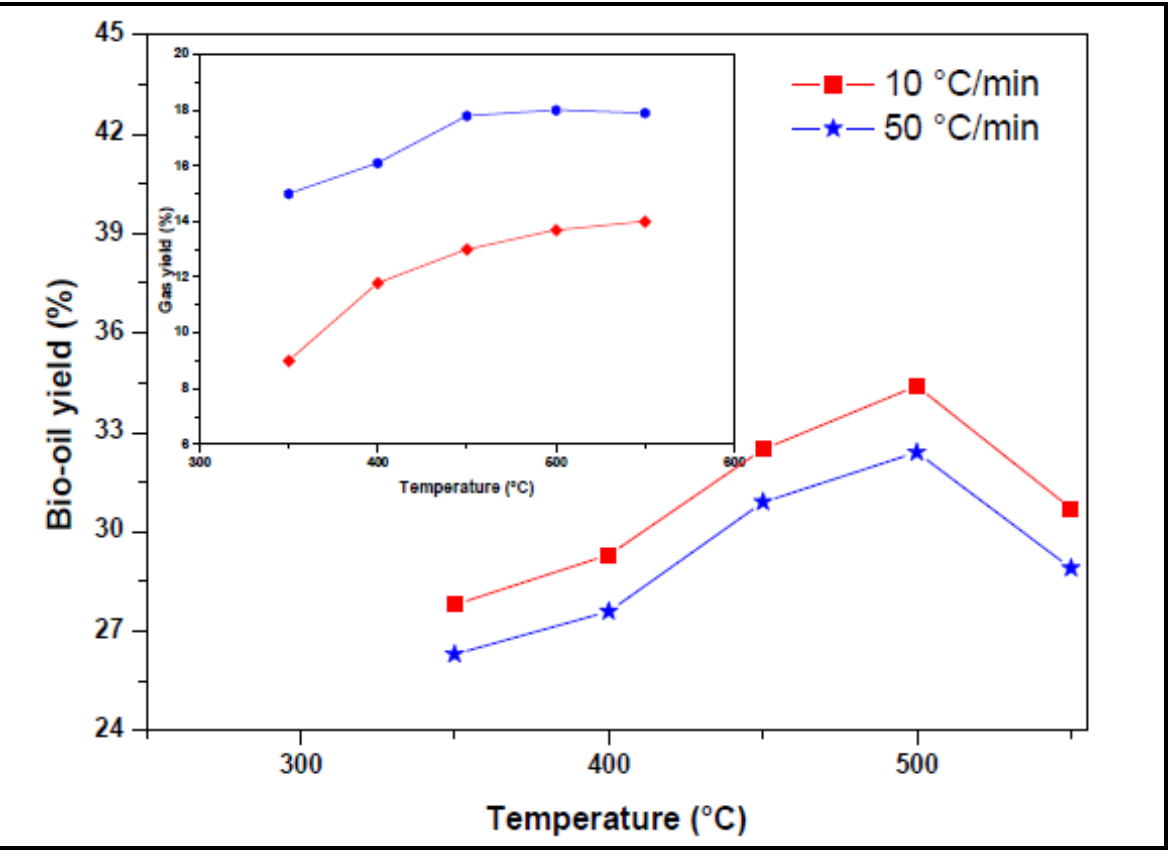

Fig. 8. Bio-oil and gas yields of olive bagasse at various heating rates and temperature [71] 
that increasing the heating rate from 10 to $50^{\circ} \mathrm{C} / \mathrm{min}$ results in the increase of gas yield and in the decrease of char yield products. Several works showed and reported a synergetic effect of heating rates on liquid oil yield. Debdoubi et al. [81] work on pyrolysis of esparto biomass at different heating rates for temperature range of $400-700{ }^{\circ} \mathrm{C}$. They found that optimum temperature for heating rate of $50{ }^{\circ} \mathrm{C} / \mathrm{min}$ and $150{ }^{\circ} \mathrm{C} / \mathrm{min}$ was $500{ }^{\circ} \mathrm{C}$ yielding $45 \%$ and $57 \%$ liquid oil. However, for $250{ }^{\circ} \mathrm{C} / \mathrm{min}$, the maximum oil yield was shifted to $550^{\circ} \mathrm{C}$.

\subsubsection{Temperature}

During pyrolysis, temperature is the most important factor with heating rates (Figs 8 and 11). The fundamental role of temperature is to afford necessary heat of decomposition to fragment biomass linkages. At relatively lower temperature, between 65 and $180{ }^{\circ} \mathrm{C}$, biomass loses its moisture, generates non-combustible gases like $\mathrm{CO}_{2}$ and undergoes depolymerisation reactions involving no significant carbohydrate loss [66-71]. Chemical bonds preconditioned in the main constituents of biomass sample begin to break at temperatures higher than approximately $200{ }^{\circ} \mathrm{C}$. Breakdown of hemicellulose, which is a less thermally stable constituent (Figs 9 and 10), takes place at lower temperatures up to $300^{\circ} \mathrm{C}$ forming gases like carbon monoxide [24, 71-74]. At temperature between 350 and $500{ }^{\circ} \mathrm{C}$ cellulose breakdowns and lignin starts to decompose resulting in charcoal, water and heavier tars. At higher temperature, gasification reactions take place forming hydrogen enriched gaseous products and char undergoes further degradation by being oxidized into $\mathrm{CO}_{2}, \mathrm{CO}$ and $\mathrm{H}_{2} \mathrm{O}$. According to these reactions it can be said that relatively low pyrolysis temperature around $400{ }^{\circ} \mathrm{C}$ favors char formation. Temperature up to $550^{\circ} \mathrm{C}$ maximizes the production of bio-oils and temperature above $700{ }^{\circ} \mathrm{C}$ maximizes gaseous products while minimizing char formation [81].

Numerous works and experimental studies [75-85], have discussed the role of temperature on liquid oil, char and gas yields. These works show that biomass conversion efficiency increases with increase in temperature, which is mainly due to extra energy inputs available to break the biomass bonds. In experiments, biomass conversion is often measured indirectly by subtracting mass of char residue from initial biomass sample. Figures 9 and 10 show the weight loss (TG) behavior of olive mill solid waste and olive mill wastewater. Mass conversion of olive wastes (OMSW and OMWW) to its fragments usually occurs in the temperature range of $250-450{ }^{\circ} \mathrm{C}$ which accounts for almost $70-80 \%$ of total conversion. However, lignin decompos- 
es over a wide temperature range unlike hemicellulose and cellulose. Several authors noted that biomass conversion is sequentially dependent upon temperature increase $[50,86]$.

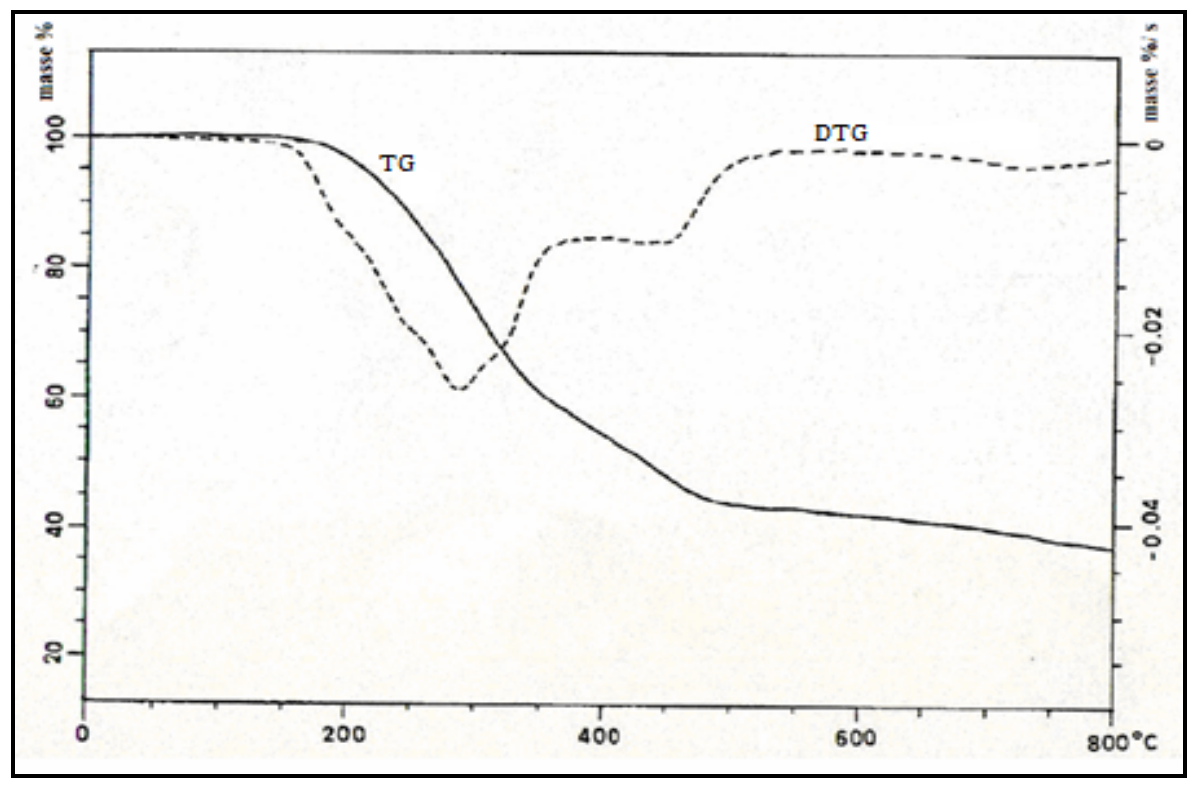

Fig. 9. DTG and TG of olive mill wastewater [95]

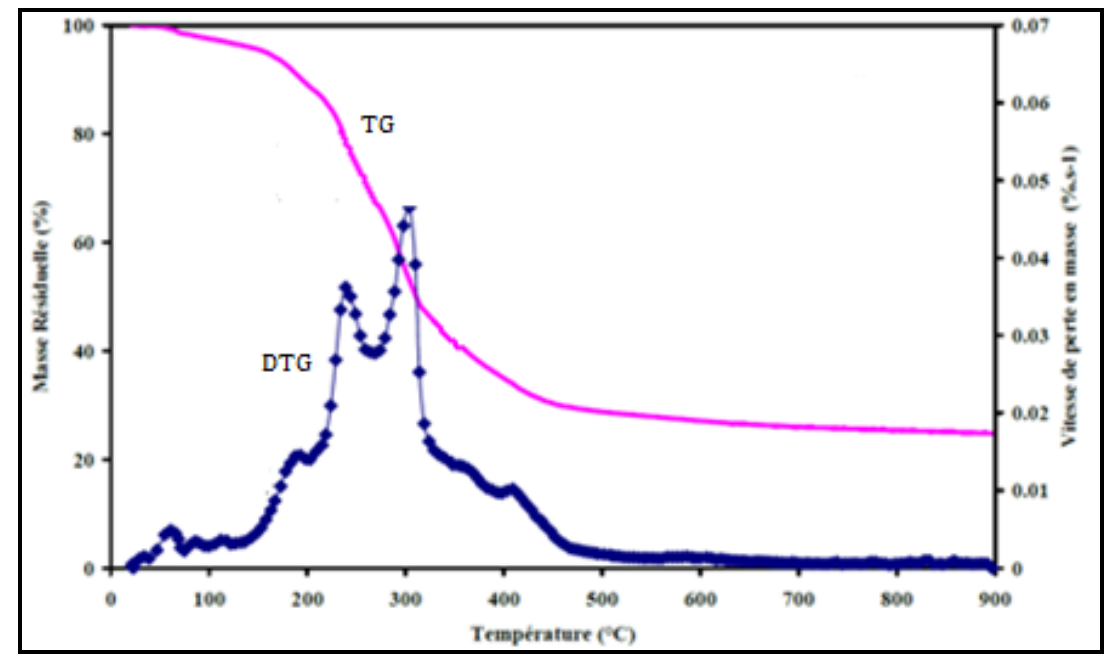

Fig. 10. DTG and TG of olive mill solid waste [41] 


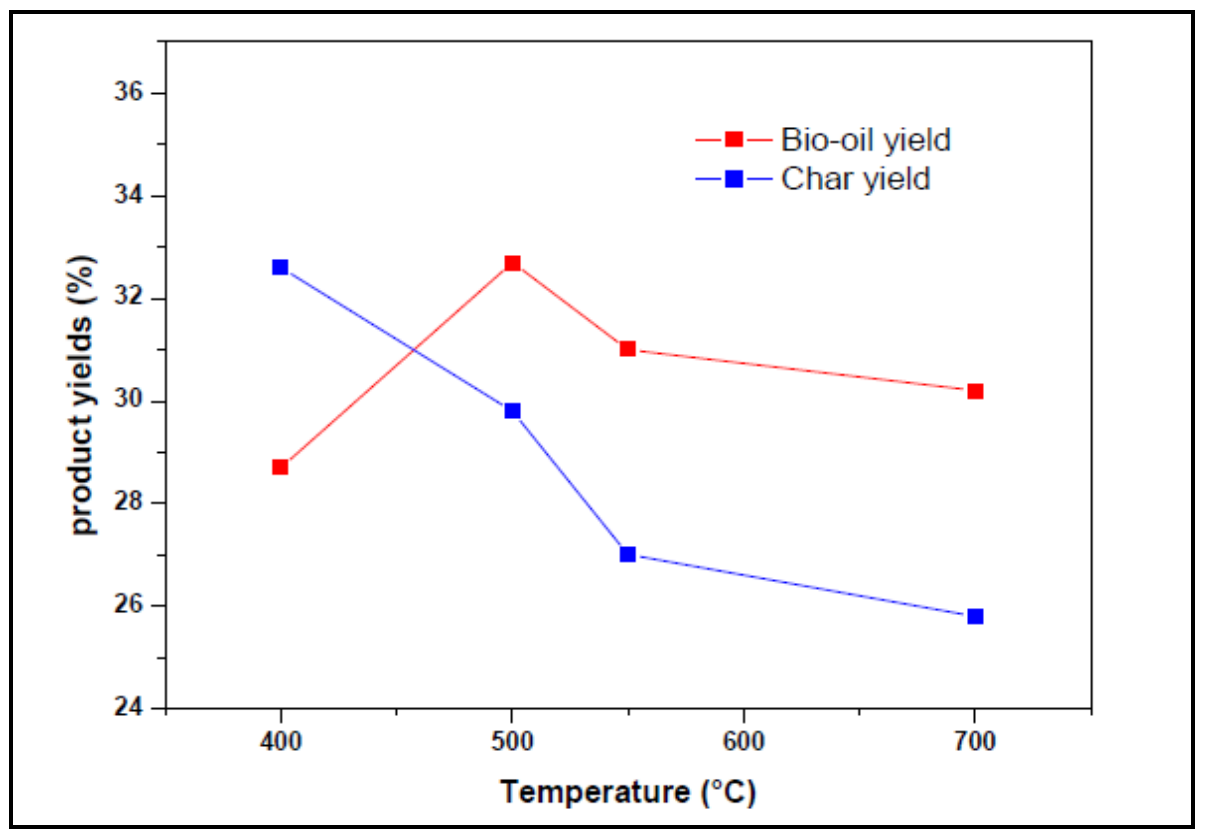

Fig. 11. Pyrolysis of olive residue at different temperature, product yields [69]

Final pyrolysis temperature affects oil, char and gas yields. In general, the bio-oil yield reaches a maximum in temperature range $400-550{ }^{\circ} \mathrm{C}$ before moving down the hill with further increase in temperature [87-89]. One can say that the variations in final temperature that give the maximum oil yield are due to the operational differences and to the biomass type. Ayse E. Pûtun et al. [92] worked on pyrolysis of olive residue under different conditions (Fig. 11), and they found that yield of conversion increased from $67.6 \%$ to $72.5 \%$ while the final temperature was increased from $400{ }^{\circ} \mathrm{C}$ to $700{ }^{\circ} \mathrm{C}$. The oil yield was $28.7 \%$ at the pyrolysis temperature of $400{ }^{\circ} \mathrm{C}$ and it appeared to go through a maximum of $32.7 \%$ at the final temperature of 500 ${ }^{\circ} \mathrm{C}$, then the oil yield decreased at $700{ }^{\circ} \mathrm{C}$. They showed that a low pyrolysis temperature favors char formation. Sergi Sensoz et al. [71] studied pyrolyse olive bagasse and the effects of pyrolysis temperature on the yield of the products, and they showed that the conversion yield increased from $61.9 \%$ to $69.4 \%$ when the pyrolysis temperature was increased from $350{ }^{\circ} \mathrm{C}$ to 550 ${ }^{\circ} \mathrm{C}$. The bio-oil yield went through a maximum $(34.4 \%)$ at the final temperature of $500^{\circ} \mathrm{C}$. The gas product yield increased with pyrolysis temperature, the gas obtained was found to be a minimum $9 \%$ at $350{ }^{\circ} \mathrm{C}$ and maximum 
$14 \%$ at $550{ }^{\circ} \mathrm{C}$. The increase in gas products is thought to occur predominantly due to secondary cracking of the pyrolysis vapors at higher temperatures. However, secondary decomposition of the char at higher temperatures may also give non-condensable gas products. Several researchers [8795] made experiments on pyrolysis of several types of biomass (rice husk, beech trunkbarks, nut shell), and they showed that thermal behavior and yields of products differed from one type to another. A. Demirbas [87] worked on pyrolysis of four nut shells (hazelnut, walnut, almond and sunflower), he showed that at elevated temperatures, the amount of char from pyrolysis of the shells decreases, the char yields at $500 \mathrm{~K}$ were 42.7, 36.3, 44.6 and $31 \%$ for hazelnut shell, almond shell, walnut shell and sunflower shell, respectively. The yields of liquid from the shell samples generally increased with the increase of temperature from 500 to $700 \mathrm{~K}$ for almond and sunflower shells and from 500 to $800 \mathrm{~K}$ for hazelnut and walnut shells and then decreased with further increasing the temperature. Concerning the yields of gaseous products, they generally increased from 650 to $1200 \mathrm{~K}$ and gases identified during the pyrolysis of shells ware $\mathrm{H}_{2}, \mathrm{CO}, \mathrm{CO}_{2}, \mathrm{CH}_{4}$ and some low molecular weight hydrocarbons.

The liquid product composition varies remarkably due to temperature variations [96]. It is known that pyrolysis oils are complex mixtures of organic compounds from different chemical groups. BinhM et al., Muzaffer $Y$ et al., T. Aysu et al. [97-99] classified organic groups found in pyrolysis oils: (1) aliphatic and aromatic nitrile; (2) long chain aliphatic amides and steroids; (3) L-alkenes and n-alkanes; (4) carboxylic acid; (5) monoaromatic hydrocarbons; (6) aromatic compounds; (7) polycyclic aromatic hydrocarbons. As the final temperature of pyrolysis increases, the functional group containing compounds experience secondary cracking thus producing more stable species $[86,90]$.

\section{Conclusion}

This paper reviews the thermochemical treatment of biomass especially biomass issue from olive oil production named olive mill wastes and some types of biomass. Olive oil production is a major agro-industry on an international scale and generates two by-products called olive mill solid waste and olive mill wastewater, which are regarded as wastes biomasses and have a negative impact on the environment and people's health. Several authors suggested solutions and alternatives to fight against the pollution of the environment by olive mill wastes and generally by agricultural biomass. Among the principal ways of valorization, one finds thermochemical con- 
version. Pyrolysis is a new thermochemical process and is considered to be the starting point for all thermochemical conversion technologies because it involves all chemical reactions to form liquid, solid and gas as the main products.

Bio-oil, char and gas production gets affected by the composition of biomass. Cellulose content in the biomass helps in the formation of tar while lignin content is favorable for char production. Minerals and extractives impact on the yields and compositions of products. Process parameters influence the product yield remarkably in pyrolysis. Among many process parameters temperature is the main parameter which controls the bio-oil, char and gas yields and their qualities. Temperature between $450{ }^{\circ} \mathrm{C}$ and $500{ }^{\circ} \mathrm{C}$ depending upon the nature and type of biomass suite the bio-oils production the most. High temperature leads to high liquid and gaseous yields and low biochar yield. Particle size, type of feedstock, heating rate and especially temperature are the main factors affecting the bio-oil, char and gas yields.

\section{References}

[1] Rapport principal. Plan national oléicole 1998-2010. Direction de Production Végétale, Ministère de l'Agriculture, de l'Equipement et de l'Environnement, Département de l'Agriculture 2009.

[2] Commercialisation et transformation des olives. Division des projets de Mise en Valeur et de l'Industrie Agricole. Direction de la Production Végétale. Effect of waste waters from olive oil extraction plants of the bacterial of soil. Chemosphere 15 (1998) 659-664.

[3] Y. Lazzeri, Les défis de la mondialisation pour l'oléiculture méditerranéenne, l'olivier en méditerranée, conférence centre culturel français de Tlemcen, Algérie (Novembre 2009).

[4] M. C. Amoretti, G. Comet. Le livre de l'olivier (1985), EDISUD.

[5] A. Annaki, M. Chaouchi. Traitement des margines mélangées avec les eaux usées urbaines par digestion aérobique. Revue Marocaine du génie civil 83 (septembre/octobre 1999) 53-57.

[6] Industrie oléicole au Maroc et son impact sur l'environnement: Propositions d'actions de lutte contre la pollution générée par les huileries d'olives 2002/2003, cas de la province de Taounate, p. 14.

[7] Rapport principal. Ministère de l'agriculture et de la pêche maritime. Veille économique, secteur oléicole, septembre 2013.

[8] Amélioration de la qualité de l'huile d'olive, Conseil Oléicole International - Madrid (2009). 
[9] Industrie oléicole au Maroc et son impact sur l'environnement: Propositions d'actions de lutte contre la pollution générée par les huileries d'olives, cas de la province de Taounate, 2003/2004, p. 14.

[10] Ryckeboer et al. Microbiological aspects of biowaste during composting in monitored compost bin. Journal of Applied Microbiology 94 (2000) 127-137.

[11] De Bertoldi et al. The biology of composting: a review. Waste Management and Research 1 (1983) 157-176.

[12] M. Tuomela et al. Biodegradation of lignin in a compost environment: a review. Bioresource Technology 72 (2000) 169-183.

[13] S. Aissam. Etude de la biodégradation des effluents des huileries (margines) et leur valorisation par production de l'enzyme tannase, 2003, p. 17.

[14] Rapport final, Industrie oléicole au Maroc et son impact sur l'environnement: Propositions d'actions de lutte contre la pollution générée par les huileries d'olives, 2003/2004.

[15] Rapport final, Inventaire du degré de pollution, Secrétariat d'état chargé de l'eau et de l'environnement, Département de l'environnement, Direction de la surveillance et de la prévention des risques, 2008.

[16] R. Loussert, G. Brousse. L'olivier, techniques agricoles et production méditerranéenne. Ed. G.P. maison neuve de Larose Paris, 1978, p. 464.

[17] A. Achkari-Begdouri. Problématiques des margines produites par les huileries et possibilités de valorisation et de traitement, Ministère de l'intérieur, Maroc, 1994.

[18] M. Ismaili-Alaoui et A. Heddoun. Tentative de modernisation des Maâsra traditionnelles. Unité mobile d'extraction des huiles d'olives. In: Ismaili Alaoui, M., Roussos, S., Perraud-Gaime, I., (Eds.), Biotechnology and quality of Olive tree products around the Mediterranean basin, Actes Editions, Rabat, Maroc, 2006, pp. 243-258.

[19] A. Nefzaoui, Importance de la production oléicole et des sous-produits de l'olivier, Etude de l'utilisation des sous-produits de l'olivier en alimentation animale en Tunisie. Étude FAO production et santé animales 43 (1984), Rome.

[20] L. Di Giovacchino, A. Mascolo, I. Seghiti. Sulle caratteristiche delle acque di vegetazione delle olive. Rivista Italiana delle Sostanze Grasse 65 (1988) 481-488.

[21] U. Bing, A. Cioni, V. Laurendi. Smaltimento-recupero delle sanse de oliva proveniente da un due fasi mediante distribuzione in campo. Informatore Agrario 47 (1994) 75-78.

[22] P. Amirante, G. C. Di Renzo, L. Di Giovacchino, B. Bianchi, P. Catalano. Evolution technologique des installations d'extraction de l'huile d'olives. Olivae 48 (1993) 4353.

[23] S. H. Beis, O. Onay, O. M. Kochar. Fixed-bed pyrolysis of sunflower seed: influence of pyrolysis parameters on product yields and composition. Energy 26 (2002) 21-32.

[24] P. Paraskeva, E. Diamadopoulos. Technologies for olive mill wastewater (OMW) treatment: a review. Journal of Chemical Technology and Biotechnology 81 (2006) 1475-1485.

[25] T. Akar et al. An attractive agro-industrial by-product in environmental cleanup: Dye biosorption potential of untreated olive pomace. J Hazard Mater 166 (2009) 1217-1225. 
[26] R. Ordonez, P. Gonzalez et al. Effet de l'amendement avec grignons d'olive sur les nutriments principaux d'un sol agricole. In: Munoz- Carpena R., Ritter A., Tascon C. (Eds), Estudios de la Zona no Saturada, 1999, ISBN: 84-699-1258-5.

[27] L. Baeta-Hall et al. Biodegradation of olive oil husks in composting aerated piles. Bioresource Technol 96 (1005) 69-78.

[28] C. Paredes et al. Characterization of olive-mill wastewater (alpechin) and its sludge for agricultural purposes. Bioresource Technol 67 (1999) 111-115.

[29] M. L. Cayuela. La production Industrielle de compost écologique à partir des déchets de moulin à huile (huileries), University of Murcia, Spain; 2004.

[30] E. Garcia-Castello et al. Recovery and concentration of polyphenols from olive mill wastewaters by integrated membrane system. Water Res 44 (2010) 3883-2892.

[31] A. G. Vlyssides et al. Integrated strategic approach for reusing olive oil extraction by-products. J Clean Prod 12 (2004) 603-611.

[32] K. Al-Malah et al. Olive mills effluent (OME) wastewater post-treatment using activated clay. Sep Purif Technol 20 (2000) 225-234.

[33] J. Sierra et al. Characterisation and evolution of a soil affected by olive oil mill wastewater disposal. Sci Total Environ 279 (2001) 207-214.

[34] P. Galiatsatou et al. Treatment of olive mill waste water with activated carbons from agricultural by-products. Waste Manage 22 (2002) 803.

[35] E. S. Aktas et al. Characterization and lime treatment of olive mill wastewater. Water Res 35 (2001) 2336-2340.

[36] T. Yangui et al. Potential of hydroxytyrosol-rich composition from olive mill wastewater as a natural disinfectant and its effect on seeds vigour response. Food Chem 117 (2009) 1-8.

[37] Di Giovacchino et al. On the characteristics of oil mills effluents. Note II. Rivista italiana delle sostanze grasse 65 (1988) 481-488.

[38] A. G. Vlyssides et al. Study of a demonstration plant for the co-composting of oliveoil processing wastewater and solid residue. Bioresource Technol 56 (1996) 187-193.

[39] K. Zein, N. Benyahia. Analyse des problèmes de l'industrie de l'huile d'olive. Contribustion spéciale de sustainable Business Associates (SESEC II) du 28-29 janvier 2003, Suisse.

[40] A. Ounas, A. Aboulkas et al. Pyrolysis of olive residue and sugar cane bagasse: Non isothermal thermogravimetrique. Kinetic Analysis, Bioressource Technology 102 (2011) 11234-11238.

[41] A. Chouchen et al. Thermal degradation of olive solid waste: influence of particle size and oxygene concentration. Resources, Conservation and Recycling 54 (2010) 271-277.

[42] P. Brachi et al. Isoconversional kinetic analysis of olive pomace decomposition under torrefaction operationg condition, Fuel Processing Technology 130 (2015) 147154.

[43] K. Chaabane and al, utilisation de différents types de grignons d'olives dans l'alimentation de lapereaux. World Rabbit Science 5 (1997) 17-21.

[44] J. Jauhiainen, I. Martín-Gullón, A. Conesa Juan, R, Font. Emissions from pyrolysis and combustion of olive oil solid waste. Journal of Analytical and Applied Pyrolysis 74 (2005) 512-517. 
[45] A. Demirbas. Effects of temperature and particle size on bio-char yield from pyrolysis of agricultural residues. Journal of Analytical and Applied Pyrolysis 72 (2004) 243-251.

[46] Md. Abu khayer et al. Olive mill waste composting : a review, International Biodeterioration and Biodegradation 85 (2013) 108-119.

[47] L. Theodora-Ioanna et al. Phenolic and antioxidant potential of olive oil mill wastes, Food Chemistry 125 (2011) 92-98.

[48] A. Chouchene et al. Combined process for the treatment of olive oil mill wastewater: Absorption on sawdust and combustion of the impregnated sawdust. Bioresource Technology 101 (2010) 6962-6973.

[49] F. Ros de Ursenos et al. Epuration des margines par digestion anaérobie en vue de leur utilisation comme source d'énergie, valorisation des sous-produits de l'olivier, 1983, pp. 131-139.

[50] A. Morisot, Tournier J. P. Répercutions agronomique de l'épandage d'effluents et déchets de moulins à huile d'olive. Agronomie. 6 (1986) 235-241.

[51] M. Mebirouk. Rejets des huileries. Développement d'un procédé intégré dans la biodégradation des polyphénols dans la margine 2002. CMPP News, $\mathrm{n}^{\circ} 11$.

[52] I. Fki. The use of polyphenolic extract, purified hydroxytyrosol and 3,4dihydroxyphenol acetic acid from olive mill wastewater for the stabilization of refined oils: a potential alternative to synthetic antioxidants. Food Chemistry 93 (2005) 197-204.

[53] I. E. Kapellakis et al. Olive oil history, production and by-product management. Reviews, Environmental Science and Biotechnology 7 (2008) 1-26.

[54] Y. Yacoub. Valorisation des sous produits. L'investisseur agricole 19 (1997) 17-18.

[55] H. Topal et al. Olive cake in a circulating fluidized bed. Fuel 82 (2003) 1049-1056.

[56] G. Martinez-Garcia et al. Olive oil waste as a biosorbent for heavy metals. International Biodeterioration and Biodegradation 58 (2006) 231-238.

[57] A. S. Stasinakis et al. Removal of total phenols from olive-mill wastewater using an agricultural by-product, olive pomace. Journal of Hazardous Materials 160 (2008) 408-413.

[58] F. Pagnanelli et al. Olive mill solid residues as heavy metal sorbent material: a preliminary study. Waste Management 22 (2002) 901-907.

[59] M. Hoogwijk et al. Exploration of the ranges of the global potential of biomass for energy. Biomass \& Bioenergy 25(2003) 119-133.

[60] I. Carlesi. Etude d'un procédé de gazéification de biomasse en ambiance plasma sur bain de verre, thèse de doctorat d'état, université de Limoges, 2012.

[61] C. François-Xavie. Nouvelles stratégies catalytiques pour la gazéification de la biomasse : Influence de métaux imprégnés sur les mécanismes de pyrolyse, thèse de doctorat d'état, université de compiége, 2012.

[62] B. B. Uzun et al. Composition of products obtained via fast pyrolysis of olive-oil residue : effect of pyrolysis emperature. J. Anal. Appl. Pyrolysis 79 (2007) 147-153.

[62] J. Akhtar et al. A review on operating for optimum liquid oil yield in biomass pyrolysis. Renewable and Sustainable Energy Reviews 16 (2012) 5101-5109.

[64] A. Roig et al. An review on olive mill wastes and their valorisation methods. Waste Management 26 (2006) 960-969. 
[65] S. Arvelakis et al. Physicohemical upgrading of agroresidues as feedstocks for energy production via thermochemical conversion methods. Biomass and Bioenergy 22 (2002) 331-348.

[66] H. Erkonak et al. Treatment of olive mill wastewater by supercritical water oxidation. J. of Supercritical Fluids 46 (2008) 142-148.

[67] R. Zanzi et al. Rapid pyrolysis of agrocultural residues at high temperature. Biomass and Bioenergy 23 (2002) 357-366.

[68] G. Taralas et al. Pyrolysis of solid residues commencing from the olive oil food industry for potential hydrogen production. J. Anal. Appl. Pyrolysis 76 (2006) 109116.

[69] A. E. Putun et al. Bio-oil from olive oil industry wastes : pyrolysis of olive residue under different conditions. Fuel Processing Technology 87 (2005) 25-32.

[70] A. Zabaniotou et al. Olive residues (cutting and kernels) rapid pyrolysis product yields and kinetics. Biomass and Bioenergy 18 (2000) 411-420.

[71] S. Sensoz etl al. Olive bagasse (Olea europea L) pyrolysis, Bioressource Technology 97 (2006) 429-436.

[72] V. Minkova et al. Effect of water vapour and biomass nature on yield and quality of the pyrolysis products from biomass. Fuel Processing Technology 70 (2001) 53-61.

[73] A. Demirbas. Effects of temperature and particle size on bio-char yield from pyrolysis of agricultural residues. J. Anal. Appl. Pyrolysis 72 (2004) 243-248.

[74] I. Demiral et al. The effect of different catalystes on the pyrolysis of industrial wastes. Bioressource Technology 99 (2008) 8002-8007.

[75] F. Ana-Rita et al. Charechterization of biomass pyrolysis tars produced in the relative absence of extraparticle secondary reactions. Fuel 70 (1991).

[76] C. Myren et al. Catalytic tar decomposition of biomass pyrolysis gas with a combination of dolomite and silica. Biomass and Bioenergy 23 (2002) 217-227.

[77] Y. Sun, J. Cheng. Hydrolysis of lignocellulosic materials for ethanol production : a review, Bioresource Technology 83 (2002) 1-11.

[78] C. Dupont et al. Study about the kinetic processes of biomass steam gasification. Fuel 86 (2007) 32-40.

[79] I. Doymaz et al. Drying characteristics of the solid by-product of olive oil extraction. Biosystemes Engineering 88 (2004) 213-219.

[80] A. Chouchene et al. Energetic valorisation of olive mill wastewater impregnated on low cost absorbent: sawdust versus olive solid waste. Energy 39 (2012) 74-81.

[81] Debdoubi et al. the effect of heating rate on yields and compositions of oil products from esparto pyrolysis. International Journal of Energy Research 30 (2006) 12431250 .

[82] A. Aboulkas et al. Co-pyrolysis of oil shale and high density polyethylene: structural characterization of the oil. Fuel Processing Technology 96 (2012) 203-208.

[83] L. Qiang et al. Selective fast pyrolysis of biomass impregnated with $\mathrm{Zncl}_{2}$ to produce furfural: Analytical Py-GC/MS study. Journal of Analytical and Applied Pyrolysis 90 (2011) 204-212.

[84] A. Sayigh. Renewable energy-the way forward. Applied Energy 64 (1999) 15-30.

[85] Y. Serdar. Pyrolysis of biomass to produce fuels and chemical feedstocks. Energy Conversion and Management 45 (2004) 651-671. 
[86] A. E. Putun et al. Fixed-bed pyrolysis and hydropyrolysis of sunflower bagasse: product yields and compositions. Fuel Processing Technology 46 (1996) 49-62.

[87] Ayhan Demirbas. Effect of temperature on pyrolysis products from four nut shells. J. Anal. Appl. Pyrolysis 76 (2006) 285-289.

[88] Ayhan Demirbas. Determination of calorific values of bio-chars and pyro-oils from pyrolysis of beech trunkbarks. J. Anal. Appl. Pyrolysis 72 (2004) 215-219.

[89] J. Rath et al. Tar crocking from fast pyrolysis of large beech wood particles. Journal of Analytical and Applied Pyrolysis 62 (2002) 83-92.

[90] J. Bermejo et al. The role of low molecular weight components in the pyrolysis of pitches. Fuel 74 (1995) 1792-1799.

[91] Z. Zhang et al. Effect of temperature and heating rate in pyrolysis on the yield, structure and oxidation reactivity of pine sawdust biochar, The University of Western Australia.

[92] A. E. Putun et al. Oil production from an arid-land plant: fixed bed pyrolysis and hydropyrolysis of euphorbia rigida. Fuel 75 (1996) 1307-1312.

[93] Cupucine Dupont et al. Biomass pyrolysis experiments in an analytical entrained flow reactor between $1073 \mathrm{~K}$ and $1273 \mathrm{~K}$. Fuel 87 (2008) 1155-1164.

[94] Ayhan Demirbas. Effect of initial moisture content on the yields of oily products from pyrolysis of biomass. J. Anal. Appl. Pyrolysis 71 (2004) 803-815.

[95] S. Vitolo et al. Treatment of olive oil industry waste. Bioreseource Technology 67 (1999) 129-137.

[96] W. T. Tsai et al. Fast pyrolysis of rice husk: Product yields and compositions. Bioresource Technology 98 (2007) 22-28.

[97] Binh M. Q. Phan et al. Evaluation of the production potential of bio-oil from Vietnamese biomass resources by fast pyrolysis. Biomass and Bioenergy 62 (2014) 74-81.

[98] Muzaffer Yasar et al. Asphalten and resid pyrolysis 2: The effect of reaction environment on pathways and selectivities, Departement of Chemical Engineering, University of Delaware, 1976.

[99] T. Aysu, M. Masuk Kucuk. Biomass pyrolysis in a fixed-bed reactor: effects of pyrolysis parameters on product yields and characterization of products. Energy 64 (2014) 1002-1025. 